\title{
PENGARUH SUPLEMENTASI ZINK (Zn) TERHADAP DIARE PADA PENDERITA UMUR 6-36 BULAN YANG DIRAWAT DI RSUD Dr. SOEDARSO PONTIANAK, KALIMANTAN BARAT
}

\author{
Jurianto Gambir ${ }^{1}$, Madarina Julia², M.Juffrie ${ }^{2}$
}

\begin{abstract}
Background: Diarrhoea is one of the major causes of infants and childhood death in Indonesia. Malnutrition and zinc deficiency in diarrhoea may lead to impaired immunity.

Objective: To assess the influence of zinc supplementation on the duration of diarrhoea and the frequency of watery stools in under-three-year-old children

Method: This was a double-blind randomized controlled clinical trial, with 31 children in the supplemented group and 33 children in the placebo group. All children had acute watery diarrhea and were given supplementation within 24 hours of admission. Daily supplementation of $20 \mathrm{mg}$ zinc was given to the experimental group.

Results: The supplemented group had a shorter hospitalization compared to the placebo. Beginning from the second day of supplementation, the frequency of watery stools in the supplemented group was significantly less than in the placebo group $(p<0.001)$. While there was a significant decrease in the concentration of zinc in the serum of the placebo group, there was a slight increase in the supplemented group.

Conclusion: Zinc supplementation can shorten hospitalization and reduce the frequency of watery stools in children with diarrhoea.
\end{abstract}

Key words: diarrhoea, zinc supplementation, under-threeyear-old children, hospitalization

\section{PENDAHULUAN}

Diare merupakan salah satu penyebab kematian balita di Indonesia. Di Kalimantan Barat, diare menempati urutan ke-7 tertinggi kematian balita (1). Pada penderita diare sering ditemukan penurunan status gizi yang disebabkan oleh adanya keluhan anoreksia serta gangguan absorbsi sehubungan dengan kerusakan mukosa usus (2).

Diare dapat mengakibatkan peningkatan pengeluaran zink dari dalam tubuh, yang selanjutnya akan mempengaruhi sistem imunitas tubuh. Penurunan imunitas akan meningkatkan risiko terjadinya diare berkepanjangan yang akan mempengaruhi status gizi $(3,4)$. Manifestasi klinik dari defisiensi zink, selain gangguan imunitas, adalah gangguan pertumbuhan dan anoreksia (5). Hal ini karena zink mempunyai peran yang sangat penting dalam metabolisme tubuh dan esensial pada berbagai fungsi enzim (6). Penelitian di India dan Bangladesh menemukan bahwa suplementasi zink pada penderita diare dapat menurunkan durasi diare dan frekuensi buang air besar serta meningkatkan status gizi $(7,8)$.

Keluaran yang meningkat disertai asupan yang berkurang dapat memperburuk keadaan status gizi penderita diare. Penurunan asupan gizi dapat disebabkan oleh adanya anoreksia yang timbul karena adanya infeksi. Timbulnya kenaikan suhu dan perasaan tidak enak di perut terutama bila disertai muntah akan juga dapat mempengaruhi nafsu makan (9).

Penelitian ini bertujuan untuk menilai pengaruh suplementasi zink terhadap lama diare dan frekuensi buang air besar cair pada penderita diare berusia 6 sampai 36 bulan di RSUD Dr. Soedarso Pontianak, Kalimantan Barat.

\section{BAHAN DAN METODE}

Jenis dan rancangan penelitian ini adalah penelitian eksperimental dengan rancangan uji klinis acak terkendali buta ganda yang dilaksanakan di Rumah Sakit Umum Daerah (RSUD) Dr Soedarso, Pontianak, Kalimantan Barat. Studi dimulai pada bulan Oktober 2002 sampai dengan bulan April 2003.

\section{Subjek Penelitian}

Pasien di ruang perawatan anak kelas III dengan kriteria inklusi, penderita diare cair akut maupun disentri, berumur 6-36 bulan, didiagnosis sudah tidak dehidrasi serta orang tuanya bersedia ikut penelitian dengan menandatangani informed consent. Sedangkan kriteria eksklusi adalah penderita diare dengan komplikasi seperti pneumonia, ensefalitis, kelainan kongenital, oedema, penyakit keganasan dan penyakit berat lainnya, penderita dengan pemberian nutrisi parenteral total, pulang atas permintaan sendiri dan telah mengalami diare lebih dari $2 \times 24$ jam. Jumlah

Politeknik Kesehatan Pontianak, Jurusan Gizi

Bagian Anak RSUP Dr. Sardjito/Fakultas Kedokteran, UGM Yogyakarta 
subjek diestimasi berdasarkan hasil penelitian di India (8)yang membutuhkan 31 subjek perkelompok dengan asumsi $10 \%$ lepas selama penelitian. Prosedur penentuan perlakuan subjek menggunakan random sederhana.

\section{Pelaksanaan Suplementasi}

Suplementasi dilakukan selama subjek dirawat di rumah sakit. Kelompok suplementasi mendapatkan sirup yang mengandung zink $20 \mathrm{mg}$ perhari. Pemberian dilakukan 2 kali dalam sehari, dengan dosis sekali pemberian $10 \mathrm{mg}$ zink. Sedangkan kelompok plasebo mendapatkan sirup tanpa mengandung zink. Suplementasi pertama kali dilakukan enumerator selanjutnya dilakukan oleh orang tua di bawah pengawasan perawat.

\section{Bahan dan Alat}

Sirup suplementasi dan plasebo berwarna dan berukuran sama, masing-masing sekitar $160 \mathrm{~mL}$. Sirup dibuat di Apotik Puji Waras Yogyakarta. Alat yang digunakan adalah formulir, timbangan bayi dengan tingkat ketelitian 50 gram, pengukur panjang badan dengan tingkat ketelitian $0,1 \mathrm{~cm}$ yang dikeluarkan oleh Direktorat Gizi Depertemen Kesehatan Republik Indonesia, spectrophotometer, centrifuge, tabung reaksi bebas mineral, pipet, spuit dan termos pendingin.

\section{Pengumpulan Data}

Data lama diare dan frekuensi buang air besar diperoleh dari hasil pencatatan yang dilakukan oleh orang tua. Kadar serum zink dianalisis dengan menggunakan metode Automatic Absorption Spectrophotometry (AAS). Pengambilan darah dilakukan sebelum suplementasi dan pada akhir suplementasi. Selanjutnya pemisahan serum dilakukan di RSUD Dr. Soedarso, Pontianak, Kalimantan Barat. Selama penelitian berlangsung sampel disimpan di freezer RS pada suhu $-4^{\circ} \mathrm{C}$. Setelah penelitian selesai sampel dibawa ke Yogyakarta dengan menggunakan freezer yang diberi es untuk mempertahankan suhu. Selanjutnya sampel dianalisis di laboratorium Kimia dan Fisika Universitas Gadjah Mada.

\section{Analisis}

Data yang terkumpul dientri dan dikoding untuk selanjutnya dianalisis. Data antropometri diolah dan dianalisis dengan menggunakan program Epi Info.

\section{HASIL DAN BAHASAN}

\section{Karakteristik Subjek}

Sejumlah 64 subjek penderita diare dibagi menjadi 2 kelompok dengan random sederhana. Tiga puluh satu $(48,4 \%)$ subjek mendapatkan sirup yang berisikan zink dan $33(51,6 \%)$ subjek mendapat sirup tanpa mengandung zink. Secara keseluruhan proporsi jenis kelamin antara laki-laki dan perempuan adalah $59,4 \%$ dan $41,6 \%$. Sedangkan berdasarkan penggolongan usia, $64,1 \%$ berusia $6-11$ bulan dan $35,9 \%$ berusia 12 22 bulan.

Lama diare sebelum suplementasi adalah 1,14 hari. Berbeda dengan penelitian di Gabus dan Sliyeg Kabupaten Indramayu, yang lama diare subjek sebelum suplementasi selama 1,92 hari (10). Sebelum suplementasi rata-rata kadar serum zink subjek sebesar $5,4 \pm 1,42 \mu \mathrm{mol} / \mathrm{L}$, atau berkisar antara $2,4 \mu \mathrm{mol} / \mathrm{L}$ sampai $8,4 \mu \mathrm{mol} / \mathrm{L}$. Untuk status gizi subjek, ditemukan $26,6 \%$ dengan kategori underweight dan $28,1 \%$ kategori wasted.

Rata-rata umur ayah secara keseluruhan adalah $31,6 \pm 5,6$ tahun sedangkan ibu 27,6 $\pm 4,7$ tahun. Lama pendidikan ayah 9,59+2,6 tahun dan ibu 9,09+4,7 tahun. Sebanyak 2 orang ibu tidak pernah sekolah. Jenis pekerjaan ayah $18,8 \%$ sebagai petani, $73,4 \%$ sebagai buruh. Sedangkan sisanya yaitu $7,8 \%$ bekerja sebagai, tukang sol sepatu, penjual es dan satpam. Pada kelompok ibu ditemukan sebanyak $20,3 \%$ yang bekerja dan $79,3 \%$ sebagai ibu rumah tangga (Tabel 1 ).

\section{Pengaruh Suplementasi Zink terhadap Hari Rawat Inap}

Penelitian ini menemukan bahwa pada saat akan pulang dari rumah sakit, 93\% subjek masih buang air besar dengan frekuensi $\geq 3$ kali dalam 24 jam sebelumnya. Sehingga data kesembuhan subjek setelah suplementasi tidak diperoleh, karena definisi sembuh adalah bila frekuensi buang air besar $<3$ kali dalam 24 jam.

Pada Tabel 2 terlihat bahwa kelompok suplementasi memiliki hari rawat lebih pendek 0,52 hari dibandingkan kelompok plasebo. Pada uji rerata didapatkan perbedaan yang signifikan lama hari perawatan antara kelompok suplementasi dan plasebo $(t=-2,04, p=0,01)$.

Selanjutnya dilakukan uji multivariat regressi linier ganda dengan mempertimbangkan variabel-variabel lain yang dianggap sebagai variabel pengganggu. 
TABEL 1. Karakteristik subjek penelitian

\begin{tabular}{|c|c|c|c|c|}
\hline Karakteristik & $\begin{array}{c}\text { Suplemen } \\
\mathrm{n}=\mathbf{3 1}\end{array}$ & $\begin{array}{c}\text { Plasebo } \\
n=33\end{array}$ & $\mathbf{t}$ atau $\chi^{2}$ & $p$ \\
\hline \multicolumn{5}{|l|}{ Orang tua } \\
\hline \multicolumn{5}{|l|}{ Umur (SD) tahun : } \\
\hline Ayah & $31,3(5,8)$ & $32,2(5,4)$ & $t=0,36$ & 0,40 \\
\hline $\mathrm{lbu}$ & $26,7(4,6)$ & $28,4(4,7)$ & $t=0,95$ & 0,18 \\
\hline \multicolumn{5}{|l|}{ Pendidikan (SD) tahun } \\
\hline Ayah & $9,6(2,2)$ & $9,6(3,0)$ & $t=0,39$ & 0,96 \\
\hline Ibu & $8,4(3,4)$ & $9,8(3,4)$ & $t=-1,62$ & 0,10 \\
\hline \multicolumn{5}{|l|}{ Pekerjaan Ayah (\%) } \\
\hline Tani & $3(9,7)$ & $9(27,3)$ & & \\
\hline Buruh & $18(58,1)$ & $17(51,5)$ & $\chi^{2}=0,50$ & 0,13 \\
\hline Swasta & $10(32,2)$ & $7(21,2)$ & & \\
\hline \multicolumn{5}{|l|}{ Pekerjaan Ibu (\%) } \\
\hline Bekerja & $4(13)$ & $9(27,0)$ & $2^{2}-208$ & 0,14 \\
\hline Ibu rumah tangga & $27(87)$ & $24(73,0)$ & $\chi=2,08$ & \\
\hline \multicolumn{5}{|l|}{ Subjek } \\
\hline \multicolumn{5}{|l|}{ Jenis kelamin (\%) } \\
\hline Laki-laki & $21(68)$ & $17(59,4)$ & & \\
\hline Perempuan & $10(32)$ & $16(40,6)$ & $\chi^{2}=1,74$ & 0,18 \\
\hline Umur (SD) bulan & $10,8(4,5)$ & $11,1(4,5)$ & $t=-0,36$ & 0,71 \\
\hline \multicolumn{5}{|l|}{ Status Gizi (Awal) } \\
\hline $\mathrm{BB} / \mathrm{U}(\mathrm{SD})^{1}$ & $-1,3(1,2)$ & $-0,9(1,3)$ & $t=-1,20$ & 0,23 \\
\hline $\mathrm{BB} / \mathrm{PB}(\mathrm{SD})^{2}$ & $-1,4(1,3)$ & $-0,9(1,3)$ & $t=-1,64$ & 0,23 \\
\hline $\mathrm{PB} / \mathrm{U}(\mathrm{SD})^{3}$ & $-0,3(1,1)$ & $-0,3(1,1)$ & $t=0,33$ & 0,97 \\
\hline $\begin{array}{l}\text { Lama hari diare sebelum } \\
\text { suplementasi }(\mathrm{SD})\end{array}$ & $1,2(0,9)$ & $1,1(0,8)$ & $t=0,19$ & 0,84 \\
\hline $\begin{array}{l}\text { Kadar }(\mu \mathrm{mol} / \mathrm{L}) \text { serum zink } \\
\text { sebelum suplementasi (SD) }\end{array}$ & $4,9(1,3)$ & $5,9(1,5)$ & $t=-1,0$ & 0,10 \\
\hline Pemberian ASI (\%) & $29(93,5)$ & $28(84,8)$ & $t=0,50$ & 0,47 \\
\hline
\end{tabular}

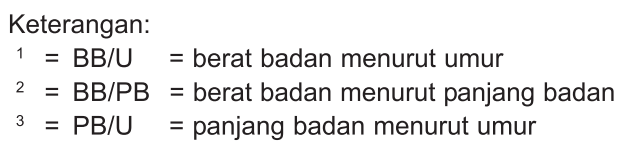

TABEL 2. Rata-rata lama rawat inap subjek

\begin{tabular}{lcccc}
\hline \multicolumn{1}{c}{ Perlakuan } & $\mathbf{n}$ & $\begin{array}{c}\text { Rata-rata hari rawat inap (SD) } \\
\text { hari }\end{array}$ & $\mathbf{t}$ & p \\
\hline Suplemen & 31 & $2,03(1,03)$ & $-2,04$ & $0,01^{*}$ \\
Plasebo & 33 & $2,55(0,60)$ & & \\
\hline Keterangan: * ${ }^{*}$ Signifikan $(p<0,05)$ & & &
\end{tabular}

Variabel tersebut meliputi: jenis kelamin, umur subjek, lama pendidikan orang tua, lama diare sebelum suplementasi serta status gizi awal yang meliputi parameter berat badan terhadap panjang badan (BB/ $\mathrm{PB})$, berat badan terhadap umur (BB/U) dan panjang badan terhadap umur (PB/U) serta pemberian $A S I$. Hasil uji regressi linier ganda menunjukkan ada 2 variabel yang berhubungan dengan hari rawat inap, yaitu suplementasi zink $(r=-0,36 p=<0,001)$ dan umur subjek $(r=-0,29, p=0,03)$.

\section{Suplementasi Zink dan Frekuensi Buang Air Besar}

Berdasarkan hasil pencatatan frekuensi buang air subjek selama suplementasi, didapatkan adanya penurunan rata-rata frekuensi buang air besar setiap hari, baik pada kelompok suplementasi dan plasebo. Akan tetapi penurunan frekuensi buang air besar lebih cepat pada kelompok suplementasi dibandingkan kelompok plasebo. Pada hari pertama suplementasi tidak ada perbedaan frekuensi buang air besar antara kelompok suplementasi dan plasebo. Perbedaan yang 
TABEL 3. Rata-rata frekuensi buang air besar harian subjek

\begin{tabular}{cccccccc}
\hline \multirow{2}{*}{ Hari ke } & \multicolumn{3}{c}{ Suplemen } & \multicolumn{2}{c}{ Plasebo } & \multirow{2}{*}{ t } & p \\
\cline { 2 - 5 } & $\mathbf{n}$ & Rata-rata (SD) & $\mathbf{n}$ & Rata-rata (SD) & & $-0,72$ & 0,47 \\
\hline 1 & 31 & $8,10(3,02)$ & 33 & $8,70(3,64)$ & & $-3,18$ & $<0,001^{*}$ \\
3 & 26 & $5,19(2,00)$ & 29 & $7,79(3,72)$ & & 2.13 & $0,04^{*}$ \\
\hline
\end{tabular}

Keterangan: * $=$ Signifikan $(p<0,05)$

signifikan ditemukan pada hari ke-2 dan ke-3 suplementasi. Kelompok suplementasi memiliki frekuensi buang air besar lebih rendah dibandingkan kelompok plasebo (Tabel 3).

Selanjutnya dilakukan uji regresi linier ganda dengan mempertimbangkan variabel umur, karena variabel umur juga mempunyai hubungan yang signifikan terhadap hari rawat subjek. Analisis regresi linier ganda menunjukkan bahwa variabel umur tidak mempunyai pengaruh terhadap frekuensi buang air besar subjek, baik pada hari ke-2 atau pun hari ke-3 suplementasi. Pada hari kedua nilai statistik dari variabel umur didapatkan $r=-1,72, p=0,09$ dan pada hari ke-3 didapatkan $r=-1,35, p=0,19$. Sedangkan variabel suplementasi tetap memberikan pengaruh terhadap frekuensi buang air besar subjek pada hari ke-2 suplementasi $(r=-3,22, p<0,001)$. Demikian pula pada hari ke-3 suplementasi $(r=-2,33, p=0,03)$.

\section{Kadar Serum Zink Subjek}

Kisaran serum zink kelompok suplementasi sebelum suplementasi adalah 2,69-6,39 $\mu \mathrm{mol} / \mathrm{L}$ dan setelah suplementasi 2,69-6,83 $\mu \mathrm{mol} / \mathrm{L}$. Sedangkan pada kelompok plasebo sebelum suplementasi kadar serum zink berkisar 2,44-8,40 $\mu \mathrm{mol} / \mathrm{L}$ dan setelah suplementasi 1,84-6,80 $\mu \mathrm{mol} / \mathrm{L}$. Pada uji t terlihat, tidak ada perbedaan rata-rata serum zink sebelum dan setelah suplementasi antara kedua kelompok perlakuan (Tabel 4).

Pada Tabel 5 terlihat bahwa ada peningkatan serum zink pada kelompok suplementasi dan penurunan pada kelompok plasebo. Setelah melakukan uji t didapatkan perbedaan yang signifikan perubahan serum zink pada kedua kelompok perlakuan.

Suplementasi yang dilakukan dalam studi ini tidak dapat menilai lama diare karena pendeknya waktu observasi. Dari analisis data diketahui bahwa 25 $(80,6 \%)$ subjek pada kelompok suplementasi mendapatkan suplementasi hanya selama 1-2 hari. Dan pada saat akan pulang dari rumah sakit $93 \%$ subjek masih buang air besar sebanyak $\geq 3$ kali dalam 24 jam sebelumnya. Sehingga perkembangan kesembuhan subjek setelah pulang dari rumah sakit tidak dapat diamati.

Suplementasi yang dilakukan memperlihatkan adanya hubungan terhadap jumlah hari perawatan subjek. Kelompok suplementasi memiliki hari rawat lebih pendek dibandingkan kelompok plasebo. Berdasarkan hasil wawancara dengan dokter yang merawat, pertimbangan dalam memulangkan subjek

TABEL 4. Rata-rata kadar serum zink sebelum dan setelah suplementasi

\begin{tabular}{|c|c|c|c|c|c|c|}
\hline \multirow{2}{*}{ Waktu } & \multicolumn{4}{|c|}{ Rata-rata kadar serum $\mathrm{Zn}$ (SD) dalam $\mu \mathrm{mol} / \mathrm{L}$} & \multirow{2}{*}{$t$} & \multirow{2}{*}{ p } \\
\hline & n & Suplemen & n & Plasobo & & \\
\hline Sebekm & 14 & $4,96(1,28)$ & 13 & $5,85(1,46)$ & $-1,67$ & 0,10 \\
\hline Setelah & 13 & $4,88 \times 1,30)$ & 10 & $4,29(1,46)$ & 1,00 & 0,32 \\
\hline
\end{tabular}

TABEL 5. Perubahan serum zink setelah suplementasi

\begin{tabular}{lccc}
\hline \multicolumn{1}{c}{ Perlakuan } & $\begin{array}{r}\text { Rata-rata perubahan kadar zink serum } \\
\text { (SD dalam Hmol/2 }\end{array}$ & $t$ & $p$ \\
\hline Suplemen $(n=13)$ & $0,07(1,88)$ & 2,17 & $0,04^{*}$ \\
Plasebo $(n=10)$ & $-1,65(1,91)$ & & \\
\hline Keterangan: ${ }^{*}=$ Signifikan $(p<0,05)$ & & &
\end{tabular}


adalah apabila keadaan subjek membaik dan frekuensi buang air besar berkurang. Pertimbangan lainnya adalah adanya peningkatan nafsu makan serta subjek bisa tidur dengan nyenyak. Berhubungan dengan pertimbangan tersebut, pada Tabel 3 terlihat bahwa kelompok suplementasi mengalami penurunan frekuensi buang air besar lebih cepat dibandingkan plasebo.

Diare dikatakan sembuh bila frekuensi buang air besar < 3 kali dalam 24 jam (11). Dengan demikian penurunan frekuensi buang air besar menggambarkan proses ke arah kesembuhan subjek. Kelompok suplementasi memiliki kecenderungan untuk lebih cepat sembuh. Hal ini berarti suplementasi yang dilakukan dapat mempercepat proses kesembuhan diare dan memiliki kontribusi dalam memperpendek hari rawat di rumah sakit.

Pada uji regressi linier ganda, variabel suplementasi dan umur memiliki kontribusi terhadap hari rawat subjek. Anak yang lebih muda cenderung untuk dirawat lebih lama. Hal ini mungkin berkaitan dengan sistem kekebalan tubuh seorang anak. Anak yang umurnya lebih muda memiliki daya tahan tubuh yang lebih rendah dibandingkan anak yang lebih tua. Hal ini sesuai dengan pernyataan Subowo (12), kemampuan untuk secara alamiah menghasilkan antibodi bertahap sesuai dengan perkembangan umur anak. Kematangan sistem imun secara penuh baru akan tercapai setelah anak berusia 10 tahun. Oleh karena itu, umur yang lebih muda juga merupakan faktor risiko masa penyembuhan yang lebih lama. Selain itu, pada usia tersebut, makanan selain ASI baru diperkenalkan dan sering ditemukan adanya malabsorbsi yang dapat menyebabkan terjadinya diare (13).

Penelitian ini menemukan perbedaan frekuensi buang air besar yang signifikan pada hari ke-2 dan ke3 suplementasi. Kelompok suplementasi mempunyai frekuensi buang air besar lebih rendah dibandingkan kelompok plasebo $(p<0,05)$. Penurunan rata-rata jumlah buang air besar pada hari ke-1 dan ke-3 lebih cepat pada kelompok suplementasi. Penurunan ini berarti adanya kecenderungan kelompok suplementasi untuk lebih cepat sembuh. Diare dikatakan sembuh jika buang air besar < 3 kali dalam 24 jam (11).

Penelitian di India juga menunjukkan bahwa suplementasi zink pada penderita diare umur 6-36 bulan dapat menurunkan frekuensi buang air besar pada kelompok suplementasi. Ditemukan kelompok suplementasi zink memiliki frekuensi buang air besar lebih rendah $39 \%$ dibandingkan plasebo (7). Di Bangladesh juga memperlihatkan bahwa suplementasi zink 20 mg perhari, pada penderita diare umur 3-24 bulan, dapat menurunkan $28 \%$ frekuensi buang air besar (8).
Mekanisme efek suplementasi zink terhadap penurunan frekuensi buang air besar mungkin berhubungan dengan perbaikan fungsi usus. Zink dapat meregenerasi epitel usus serta memperbaiki fungsinya dalam mengabsorbsi air dan natrium (7). Pada keadaan defisiensi zink, absorbsi air dan mineral akan menurun dan akan pulih kembali setelah pemberian suplementasi zink (14).

Suplementasi zink juga akan meningkatkan zink di dalam serum yang akan mempengaruhi sistem imunitas tubuh (15). Suplementasi zink akan meningkatkan immunoglobin A(slgA) sekretorik (8). Selain itu zink sulfat mempunyai kemampuan dalam menghentikan pertumbuhan bakteri penyebab diare (14).

Suplementasi yang dilakukan dalam penelitian ini dapat meningkatkan kadar serum zink, yang selanjutnya mempengaruhi immunitas. Penurunan frekuensi buang air besar sejak hari ke-2 suplementasi memberikan kontribusi untuk menghindari terjadinya dehidrasi. Di samping itu hasil penelitian ini menunjukkan adanya kecenderungan hari perawatan lebih pendek pada kelompok suplementasi.

\section{KESIMPULAN DAN SARAN}

Pada penelitian ini kelompok suplementasi memiliki hari rawat lebih pendek dibandingkan kelompok plasebo. Suplementasi zink yang diberikan dapat menurunkan frekuensi buang air besar lebih cepat sejak hari ke-2 suplementasi.

Suplementasi zink pada penderita diare selama dirawat di rumah sakit dapat dipertimbangkan untuk menurunkan frekuensi buang air besar. Perlu dilakukan studi lanjut dengan mengobservasi subjek sampai ke rumah untuk melihat efek suplementasi zink selanjutnya, misalnya terhadap asupan makan dan pertumbuhan.

\section{RUJUKAN}

1. Departemen Kesehatan. Profil Kesehatan Indonesia. Jakarta; 1997.

2. Lanata CF, and Black RE. Diarrheal Diseases. In: Richard Semba \& Martin W Bloem, editors. Nutrition and Health in Developing Countries New Jersey: Human Press; 2000. p. 93-7.

3. Wapnir RA. Zinc Deficiency, Malnutrition and Gastrointestinal Tract. J Nutr 2000;130:1388-92.

4. Hidayat, Achadi, Sunoto, Soedarmo. Pengaruh Pemberian Seng terhadap Diare Memanjang pada Anak Balita. Majalah IImu Fak.kedokteran 1998;17:71-78. 
5. Shrimpton R. Zinc Deficiency. In: Richard Semba and Martin W Bloem, editors. Nutrition and Health in Developing Countries. New Jersey: Humana Press; 2000. p. 307-26.

6. Linder CM. 1985. Biokimia Nutrisi dan Metabolisme. $1^{\text {st }}$ ed (Terjemahan). Prakkasi A. Jakarta: Universitas Indonesia; 1992.

7. Sazawal S, Blak RE, Bhan MK, Bhandari N, Sinha A, Jalla S. Zinc Supplementation in Young Children with Acute Diarrhea in India. N Engl J Med 1995:13;839-44.

8. Roy SK, Tomkins MA, Akramuzzaman, Behrens $\mathrm{RH}$, Mahalanabis D, Fuchs G. Randomized Controlled of Zinc Suplmentation in Malnourished Banglades Children with Acute Diarrhoea. Arch Dis Child 1997;77:196-200.

9. Partawihardja. Pengaruh Suplementasi Tempe terhadap Kecepatan Tumbuh pada Penderita Diare Anak Umur 6-24 Bulan [disertasi]. Semarang: Universitas Diponegoro; 1990.
10. Hidayat A. Pengaruh Pemberian Seng terhadap Diare Memanjang pada Anak Balita. Majalah IImu Fak. Kedokteran 1998:17;1-78.

11. Nelson. IImu Kesehatan Anak. $15^{\text {th }}$ ed (Terjemahan). Siregar MR, dan Maulany RF. Jakarta: EGC; 1996.

12. Subowo. Imunolobiologi. Bandung: Angkasa; 1993.

13. Suryono A. Isu Penelitian pada Peningkatan Pola Pemberian Makanan Bayi untuk Penanggulangan Diare. Berita Kedokteran Masyarakat 1988:4(12); 327-33.

14. Lesmana S, HidayatA. Kadar Hambatan Senyawa Seng Sulfat terhadap Beberapa Jenis Kuman Enteropatogen. Majalah IImu Kedokteran 1999;18: 53-60.

15. Butta ZA, Nizami SQ, Isani Z. Zinc Supplementation in Malnourished Children with Persisten. Pediatrics [series online] 1999 April;103(4):[25 screens]. Available FTP: Hostname: kfschrc.edu. sa/annals/ 215_216/01-017SR.pdf+\&hl=en\&ie= UTF-8. $(1-16)$ 